\title{
HOW TO FIND A STONE CRAYFISH \\ AUSTROPOTAMOBIUS TORRENTIUM (SCHRANK, 1803): A BIOGEOGRAPHIC STUDY IN EUROPE
}

\author{
Y. MACHINO (1) and L. FÜREDER (2)
}

(1) Higashi-Monzen-cho 520-4, Sakyo-ku, Kyoto 606-8345, Japan.

E-Mail: yoichi.machino@fnac.net

(2) Institut für Zoologie und Limnologie, Universität Innsbruck, Technikerstraße 25, A6020 Innsbruck, Austria.

E-Mail: leopold.fuereder@uibk.ac.at

Reçu le 2 février 2005

Accepté le 6 Juillet 2005

Received February 2, 2005

Accepted July 6, 2005

\begin{abstract}
The stone crayfish Austropotamobius torrentium (Schrank, 1803) is widely distributed in Southeastern and Central Europe. However, this information has not been verified until recently because of:

- ignorance about biogeographic notion and hydrography and

- ignorance of data in the literature.

Overcoming these problems during the last decade, the distribution pattern of the stone crayfish has now become apparent in Europe. It is known from Luxembourg and Germany to the west, from Turkey to the east, from Germany and the Czech Republic to the north and from Greece to the south. It is absent in the northeastern part of the Pannonian basin as well as in Poland and Ukraine. Its presence in Luxembourg and the Czech Republic may be related not to natural distribution but to introduction by humans through history. The discovery of the stone crayfish in Italy and Turkey as well as its re-discovery in France during the 1990s proves the biogeographic conception that this animal belongs to the Danubian fauna. It probably originates from the southwestern part of the Pannonian basin.
\end{abstract}

Key-words: crayfish, Astacidae, Austropotamobius torrentium, biogeography.

\section{COMMENT TROUVER UNE ÉCREVISSE DES TORRENTS AUSTROPOTAMOBIUS TORRENTIUM (SCHRANK, 1803) : UNE ÉTUDE BIOGÉOGRAPHIQUE EN EUROPE}

\section{RÉSUMÉ}

L'écrevisse des torrents Austropotamobius torrentium (Schrank, 1803) est largement répandue en Europe centrale et en Europe du sud-ouest. Mais cette information n'a pas été vérifiée jusqu'à récemment à cause de :

- la négligence sur la notion biogéographique et l'hydrographie.

- la négligence sur les données dans la litérature.

Surmontant ces problèmes durant la dernière décennie, la mode («pattern ") de répartition de l'écrevisse de torrent est enfin devenue visible en Europe. Cette écrevisse est connue au Luxembourg et en Allemagne à l'ouest, en Turquie à l'est, en Allemagne et 
en République tchèque au nord et en Grèce au sud. Elle est absente dans la partie nordest du bassin Pannonien et également absente en Pologne et Ukraine. Sa présence au Luxembourg et en République Tchèque pourrait être liée non à la répartition naturelle mais à des introductions artificielles faites par les hommes. La découverte de l'écrevisse de torrent en Italie et en Turquie et sa redécouverte en France durant les années 1990 prouvent la conception biogéographique que $A$. torrentium appartient à la faune danubienne. Cette espèce est probablement d'origine de la partie sud-ouest du bassin Pannonien.

Mots-clés : écrevisse, Astacidae, Austropotamobius torrentium, biogéographie.

\section{INTRODUCTION}

The stone crayfish Austropotamobius torrentium (Schrank, 1803) is widely distributed throughout Central and Southeastern Europe (LAURENT, 1988). Although the global and general view of its geographical distribution seems to be known (LAURENT, 1988; HOLDICH, 2002), details and exact regional or local patterns are quite hazy. Many people believe or feel that such information does not exist. Biologically and biogeographically this species is believed to be much less known than the noble crayfish Astacus astacus (Linnaeus, 1758), the narrow-clawed crayfish Astacus leptodactylus Eschscholtz, 1823 and the white-clawed crayfish Austropotamobius pallipes (Lereboullet, 1858). This is one of the reasons why the $4^{\text {th }}$ Craynet Meeting Innsbruck 2004 was focused on the stone crayfish.

Since 1994 we have been studying the stone crayfish at the European level. We quickly understood that the stone-crayfish information existed in the literature as well as on the local level in every country. Although it was believed that such information did not exist because most likely people had not looked for it; we herein prove the contrary: in tracking important information and verifiying it, we show how to find stone crayfish in Europe. By indicating our crayfish hunting techniques and considering a standard protocol for crayfish searching, we present new data on the distribution pattern and give some ecological notes of this poorly known European crayfish species. Majority of the information mentioned below comes from our crayfish studies and observations carried out between 1994 and 2004.

\section{METHODS, RESULTS and DISCUSSION}

\section{Historic of our stone-crayfish hunting}

Austria - Tyrol: When we started our crayfish studies in 1994 in Tyrol (Austria), we did not know how and where to find the stone crayfish in Tyrol. There was no published information available at all. We began with Lake Plansee because we knew there were crayfish, which were revealed to be $A$. pallipes (FÜREDER and MACHINO, 1995). And later near Lake Plansee, we had information about crayfish of the River Archbach. The crayfish of the lower part of the Archbach has been shown to be $A$. torrentium (FÜREDER and MACHINO, 1996). This was our first stone crayfish. At that time we looked for it in all kinds of waters rather randomly because we did not know the exact methodology, as the correct information was not available in the literature then.

Austria - Carinthia: In 1994 we also began the crayfish study in western Carinthia but we targeted waters very randomly, as we had very little information about Carinthian crayfish in the literature then.

We started developing experiences on the local level, i.e., Austria (Tyrol and Carinthia), in 1994 and quickly these were extended at the European level. The next remarks were noticed since. 


\section{Remarks}

A general view on the distribution pattern of $A$. torrentium was given by LAURENT (1988). It clearly indicates that the species belongs to the Danubian fauna. Thus biogeographic notion can be indicative: where they live and where they expand. Also the biogeographic pattern of other aquatic animals is very important. As $A$. torrentium is a member of the Danubian fauna, its presence is always accompanied by other representatives of the Danubian fauna. This is a very important indication, particularly when it is present in hydrographic basins beyond the Danube system.

The paper of HART and CLARK (1987) belongs to the most important crayfishliterature data. But this seems not to have been exploited by the European scientists. When this paper is exploited well, many important references become apparent and the crayfish distribution pattern in Europe appears in detail, e.g., in Hungary, Romania and Bulgaria. Thus the $A$. torrentium distribution pattern in southern Europe becomes obvious and the presence of $A$. torrentium in several Greek territories and even in Turkey has to be expected.

The taxonomic confusion between $A$. torrentium and $A$. pallipes occurred until the beginning of the 1920s although the former was described in 1803 and the latter in 1858. The confusion was corrected by ENTZ $(1909,1914)$ and CARL (1920).

Other shortcomings appear when investigating the distribution of crayfish. Although local information on crayfish presence always exists, usually not many scientists look for that information. In addition, as it requires administrative authorizations for catching crayfish, which are generally not easily obtained, it is difficult to study indigenous crayfish in some countries.

\section{Standard protocol for the crayfish hunting}

These experiences and remarks enabled us to learn the importance and usefulness of the topographic as well as hydrographic information. We always look for the topographic maps before the crayfish observation. Moreover, both the literature data and the local information appear to be the most efficient sources for finding crayfish waters. We start our crayfish observation with the next steps :

Step 1 - Analyzing many references on the biogeography of the Danubian fauna. This is a difficult task, as there are so many Danubian animals, i.e., it is almost impossible to read all the papers. So, we followed some particular classes of the animals in order to have the biogeographic notion of these particular animals. Especially, the fish biogeography (e.g., BERG, 1932; THIENEMANN, 1950; BANARESCU, 1990/1995) helped a lot in our case.

Step 2 - Analyzing HART and CLARK (1987) for extracting all important references on the stone crayfish.

Step 3 - Analyzing all the references on the stone crayfish found in HART and CLARK (1987) and other stone-crayfish references found in elsewhere.

Step 4 - Analyzing the crayfish references, treating every aspect of the crayfish biogeography in Europe. These included documents on human history, geography, fisheries, zoology, etc.

Step 5 - Analyzing the hydrographic situation using maps.

The steps 1 to 5 allow us to know the possible stone-crayfish situation of every corner in Europe, i.e., where to go and do the crayfish observation. The next steps are:

Step 6 - Analyzing the topographic situation after topographic maps and ecological situation at the sites. 
Step 7 - Looking for local information from local people and institutions. Local farmers, hunters, fishermen, policemen, professors, teachers, fishing guards, forest guards, town/village mayors and children are asked.

The steps 6 to 7 enable us to target waters and places. The next steps are:

Step 8 - Before the night observation, a daytime pre-observation is necessary. This allows us to find most likely the crayfish spots.

Step 9 - Crayfish catching by hand (daytime and/or night-time).

Step 10 - Nighttime observation with a lamp.

Step 11 - Crayfish catching by crayfish traps.

Thus once all the information and situations had been analyzed, we targeted waters and places where we were most likely to find crayfish. Then we try to catch the stone crayfish. This method became our standard protocol for geographical distribution studies of the indigenous crayfish.

\section{Application of the protocol: searching for A. torrentium}

\section{Czech Republic}

A. torrentium is known only from the Elbe drainage (i.e. Bohemia) and seems to be absent in the Danube drainage (i.e. Moravia) (LOHNISKY, 1984a, 1984b, 1990; POLICAR and KOZÁK, 2000; DURIS et al., 2001; KOZÁK et al., 2002). The distribution pattern in the Elbe drainage (i.e. no logical biogeographic pattern) allows us to "suppose" that this may be an introduction by man (MACHINO and HOLDICH, in press).

\section{France}

For the French $A$. torrentium, the important paper is LEREBOULLET (1858). Some taxonomic confusion seems to have occurred between $A$. torrentium and $A$. pallipes, however, only the specimens studied by LEREBOULLET were verifiable. These A. torrentium were from a population near Strasbourg. But the population has already disappeared (probably in the $19^{\text {th }}$ century).

Till the 1980s, nobody looked for A. torrentium in Alsace and Lorraine. Since the 1990s, three populations of $A$. torrentium have been found (two in Lorraine and one in Alsace) (FRANCKHAUSER and MACHINO, 2000, 2001; HORNIER et al., 2002). Two are still present, but one from Lorraine is probably extinct (FRANCKHAUSER and MACHINO, 2001; CHANGEUX, 2003).

\section{Germany}

Austropotamobius torrentium has been known only from the Middle and Upper Rhine drainages and the Danube drainage as well as the headwaters of the Eger River (=Ohře; Elbe drainage) (BERG et. al., 1989; SCHANZ and FROEHLICH, 1991; STEINBERG, 1992; SCHADT, 1993; TROSCHEL and DEHUS, 1993; BOCK et al., 1996; DEHUS, 1997; KAPPUS et al., 1999; REPA, 1999; BOHL, 2000; BOHL et al., 2001; KLOS and KROTTEN, 2001; MEINEL and MOCK, 2001).

\section{Greece}

Austropotamobius torrentium has been known from northern Greece (BOTT, 1972; KINZELBACH, 1986), but searching for it in other parts of Greece, the crayfish information from Bulgaria (e.g., BULGURKOV, 1961) is important. In 1996 the information allowed us to find several $A$. torrentium populations in eastern Greece (Struma drainage, Mesta drainage and one isolated karstic hydrography) (MACHINO and $\mathrm{HOLDICH}$, in press). 
Italy

No historical papers on $A$. torrentium existed. The biogeographic conception was neglected, and nobody suspected the $A$. torrentium presence in the Italian Danubian water (Slizza drainage). DE LUISE $(1988,1991)$ reported " $A$. pallipes" there by identification error. MACHINO (1996) corrected the error, it is A. torrentium. Up to now, we have found three populations in the Slizza drainage near Tarvisio, but one of them probably extinct already (MACHINO and HOLDICH, in press).

\section{Luxembourg}

Very few papers existed for the historical crayfish data. TROSCHEL and BARTL (1998), MACHINO $(2000,2001)$ and FRANCKHAUSER and MACHINO (2002) are useful. ATTEN (1987) indicates that $A$. torrentium is not indigenous. Also the crayfish data from German provinces of Saarland and Rheinland-Pfalz (Machino, unpub. data) indicate that A. torrentium is non-indigenous to Luxembourg.

\section{Poland}

Up to now, no $A$. torrentium has been found in Poland. There are a few papers mentioning its presence in Poland (e.g., STAROBOGATOV, 1995), but no verifiable data and papers on the Polish $A$. torrentium are available.

\section{Turkey}

Nobody seemed to have suspected the presence of $A$. torrentium in Turkey. But the information on the Bulgarian crayfish (BULGURKOV, 1961) provides such possibility. Also the biogeographic information on other freshwater fauna indicates this country may/ should have $A$. torrentium. Indeed, one population was found in the European part of Turkey in 1996, i.e., in the Velika River (Rezovska drainage).

\section{Ukraine}

Up to now, no $A$. torrentium has been found in Ukraine. The reported presence of $A$. torrentium in the headwaters of the Stokhod River in Ukraine (Dniepr drainage) (KARAMAN, 1962) seems to be an error on the sampling location (MACHINO and $\mathrm{HOLDICH}$, in press).

\section{Some ecological notes on stone crayfish}

Mostly stone crayfish live in running waters, but they can also exist in stagnant waters like Lake Haldensee in Austria (MACHINO and FÜREDER, 1998) or Lake Blejsko jezero in Slovenia (BUDIHNA, 2004 pers. com.). Except this high preference for rheophilic waters and the avoidance of muddy areas, the habitats of stone crayfish are very similar to those of two other European crayfish (A. pallipes and $A$. astacus). We here indicates some remarks on its habitat and ecology. As references on the stone-crayfish ecology are rather recent and still relatively rare (e.g., SCHULZ and KIRCHLENER, 1984; BOHL, 1989, 1999; PETUTSCHNING, 1993; BITTERMANN, 1998; KAPPUS et al., 1999; RENZ and BREITHAUPT, 2000; MAGUIRE et al., 2002; STREISSL and HÖDL, 2002), most of the remarks come from our observations on the fields:

- Steepness: difficult to say. If very steep brooks, the water flow must be low for a good spot for stone crayfish. They like stable grounds. Typical torrents are generally not good for them.

- Width of rivers and brooks: Generally less than 10 or $15 \mathrm{~m}$ wide, but it can be much wider. One of us (Y.M.) saw stone crayfish in the Lim River (Montenegro) with 40 or $50 \mathrm{~m}$ width. In another large river in Montenegro (the Tara River), stone crayfish are 
present in hyporhithron a few kilometers below the town Kolašin, while they are absent in metarhithron above Kolašin. In brooks, they generally occur in metarhithron, and they can occur in epirhithron if the water flow is low. In another sentence, the epirhithron is generally not a good habitat for stone crayfish.

- Bottom: stones and gravels, but not sand nor mud. The bottom must be stable. Stone crayfish often make burrows like other European crayfish species. With sand, they cannot dig burrows.

- Temperature: variable, but the data for the temperature limits are not available to us. All the stone-crayfish rivers we know offer a nice temperature for people to swim in summer.

- Vegetation: prairie or deciduous forests. Coniferous forests are not inducive to crayfish survival. Probably because coniferous trees tend to make the soil acid and their leaves seem not to be used by the crayfish as food.

- Water pollution: stone crayfish are very sensitive to water pollution. In Western Europe, the presence of houses with detergents and agricultural activities with pesticides is indicative for the absence of stone crayfish. Wider presence of these animals in large rivers in Eastern Europe would be related to relative absence of these pollutants. Also eutrophication of water by human activities decreases or destroys the habitat of the stone crayfish. Presence of large areas of riparian vegetation as well as water plants within brooks or rivers is one of very important factors for survival strategies of stone-crayfish populations that live in such badly polluted waters.

\section{Origin of $A$. torrentium}

The crayfish papers from Bulgaria (ARNDT, 1943; BULGURKOV, 1961; SUBCHEV and STANIMIROVA, 1998), Romania (SCRIBAN, 1908; ENTZ, 1909, 1914; CALINESCU, 1929; MARCU, 1930; BACESCU, 1967), Hungary (ENTZ, 1909, 1914; WOLSKY, 1934; THURÁNSZKY and FORRÓ, 1987; PUKY, 2000), Slovakia (ORTVAY, 1902; ENTZ, 1909, 1914; MATIS, 1971; HALGOS, 1972; JANSKY, 1987) and the Czech Republic (see above) are not used sufficiently by the scientists from Western Europe. These papers reveal that $A$. torrentium is almost absent in the northeastern areas of the Pannonian basin as well as in the Lower Danube drainage (below the Olt drainage in Romania) (Fig. 1). Our prospection in the Danube drainage of several countries (Ukraine, Poland, the Czech Republic, Slovakia, Hungary and Romania) supports this opinion.

On the other hand, $A$. torrentium would have originated from somewhere in the southwestern part of the Pannonian basin, where Slovenia, Croatia, Bosnia and Herzegovina and Serbia lie today. The species is widely distributed within this area and recent studies based on Cytochrome Oxydase I (COI) sequence analyses support this opinion (TRONTELJ et al., 2005). From the original distribution area, then through the evolution history, A. torrentium reached river basins of the Aegean Sea (Greece, Macedonia, Serbia, Bulgaria), Black Sea (Bulgaria, Romania, Turkey) and Upper Danube drainage (Germany, Austria), thus allowing them to extend the geographical distribution to the Rhine drainage (France, Switzerland, Germany, Austria) as well as the Drin drainage (Montenegro, Albania, Serbia, Macedonia and Greece) (BOTT, 1972; ALBRECHT, 1982; MACHINO and DURIS, 2004).

\section{ACKNOWLEDGEMENTS}

We heartly thank the unknown referees and the editors. Their helps were precious. 


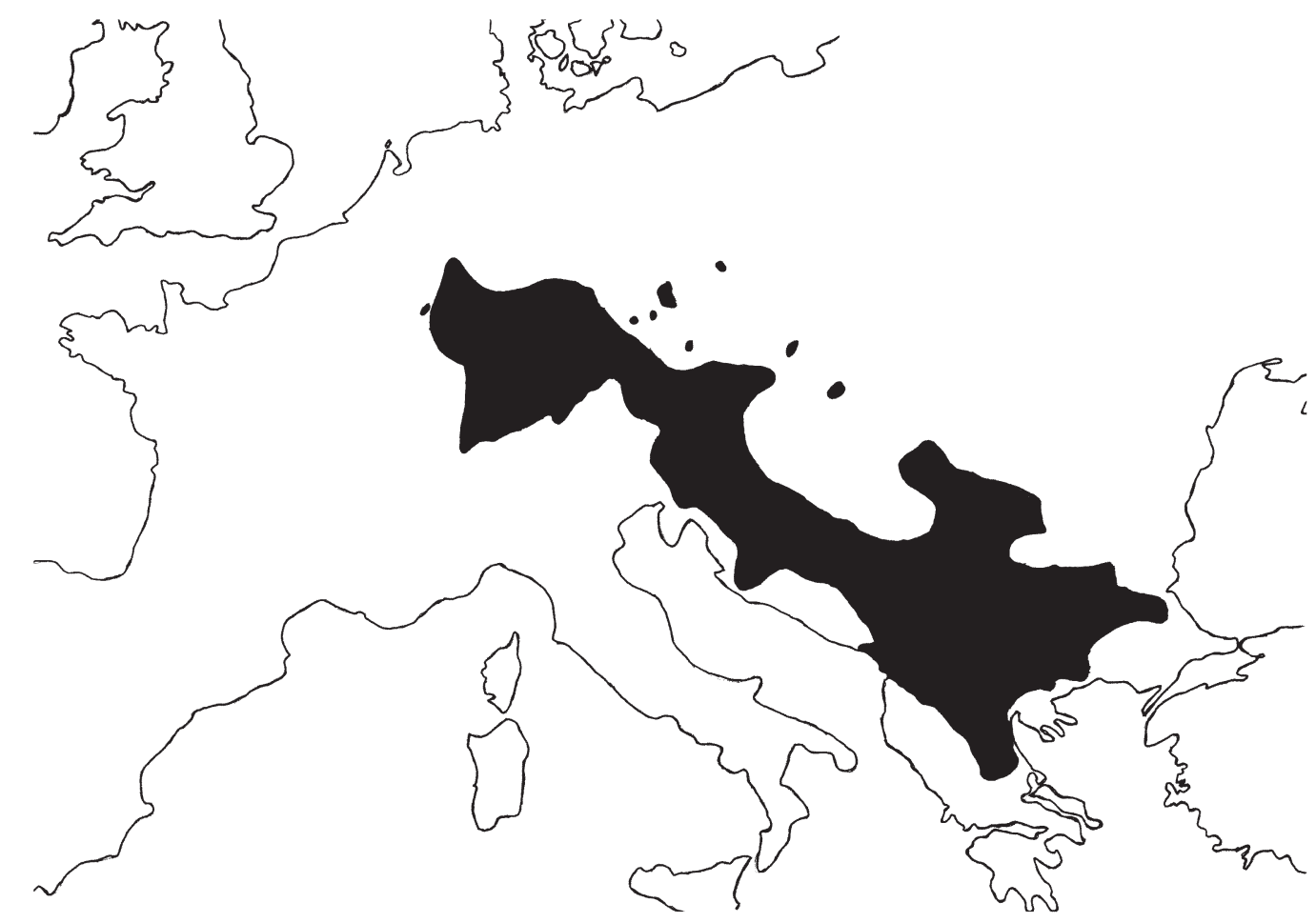

Figure 1

Geographical distribution of Austropotamobius torrentium in Europe.

Figure 1

Répartition géographique d'Austropotamobius torrentium en Europe.

\section{REFERENCES}

ALBRECHT H., 1982. Das System der europäischen Flußkrebse (Decapoda, Astacidae): Vorschlag und Begründung. Mitt. Hamb. Zool. Mus. Inst., 79, 187-210.

ARNDT W., 1943. Beiträge zur Kenntnis der Süsswasserfauna Bulgariens. Izvestija na Carskite Prirodonaučni Institut v Sofija, 16, 189-206.

ATTEN D., 1987 unpublished. Etude des populations d'écrevisses d'eau douce au Grand-Duché de Luxembourg et spécialement de l'écrevisse de Californie (Pacifastacus leniusculus). Mémoire de stage pédagogique, Service Chasse et Pêche, Administration des Eaux et Forêts de Luxembourg, Luxembourg, v + $190 \mathrm{p}$.

BACESCU M.C., 1967. Decapoda. Fauna Republicii Socialiste România, 5 (9), 353 p. + 2 pl. Academia Republicii Socialiste România, Bucarest.

BANARESCU P., 1990/1995. Zoogeography of fresh waters. AULA Verlag, Wiesaden, 3 vols: $1617 \mathrm{p}$.

BERG L., 1932. Übersicht der Verbreitung der Süßwasserfische Europas. Zoogeographica (Jena), 1 (2), 107-208 + pl. 2.

BERG R., BLANK S. and STRUBELT T., 1989. Fische in Baden-Württemberg. Ministerium für ländlichen Raum, Ernährung, Landwirtschaft und Forsten, Stuttgart, 158 p. 
BITTERMANN W., 1998. Der Steinkrebs Austropotamonbius torrentium in Wien. Stapfia (Linz), 58 (137), 29-36.

BOCK K.H., BÖSSNECK U., BRETTFELD R., MÜLLER R., MÜLLER U. and ZIMMERMANN W., 1996. Fische in Thüringen. Referat Öffentlichkeitsarbeit (Abteilung Zentral Dienst), Thüringer Ministerium für Landwirtschaft, Naturschutz und Umwelt, Erfurt, vii $+120 \mathrm{p}$

BOHL E., 1989. Ökologische Untersuchungen an ausgewählten Gewässern zur Entwicklung von Zielvorstellungen des Gewässerschutzes - Untersuchungen an Flußkrebsbeständen. Berichte der Bayerischen Landesanstalt für Wasserforschung (München), 13, x +237 p. +2 pl.

BOHL E., 1999. Crayfish stock situation in Bavaria (Germany) - attributes, threats and chances. Freshwater Crayfish, 12, 765-777.

BOHL E., 2000. Krebse. In Bayerische Landesanstalt für Fischerei (ed.), Ergebnisse der Artenkartierungen in den Fließgewässerrn Bayerns: Fische, Krebse, Muscheln. Bayerisches Staatsministerium für Ernährung, Landwirschaft und Forsten, München, p. 169-183.

BOHL R., KELLER M. and OIDTMANN B., 2001. Flusskrebse in Bayern. Broschüre, Landesfischereiverband Bayern, München, $36 \mathrm{p}$.

BOTT R., 1972. Besiedlungsgeschichte und Systematic der Astaciden West-Europas unter besonderer Berücksichtung der Schweiz. Rev. Suisse Zool., 79 (1), 387-408 +4 pl.

BUDIHNA N., 2004 pers. com. Zavod za Ribištvo Slovenije, Župančičeva 9, SLO-1000 Ljubljana, Slovenia.

BULGURKOV K., 1961. Sistematika, biologija i zoogeogravsko razprostranenie na sladkovodnite raci ot sem. Astacidae i sem. Potamobidae v Bylgarija. Izvestija na Zoologičeskija Institut s Muzej (Sofia), (10), 165-192.

CALINESCU R.I. ,1929. Astacus torrentium Schrank, în Muntii Olteniei. Revista Arhivelor Olteniei (Craiova), 8 (41/42), 106-109.

CARL J., 1920. Decapode (écrevisses). Catalogue des invertébrés de la Suisse, (fascicule 12), iii + 35 p. Georg, Genève.

CHANGEUX T., 2003. Évolution de la répartition des écrevisses en France métropolitaine selon les enquêtes nationales menées par le Conseil Supérieur de la Pêche. Bull. Fr. Pêche Piscic., 370/371, 15-41.

DE LUISE G., 1988. Indagine preliminare sulla distribuzione del gambero di acqua dolce della species Austropotamobius pallipes italicus (FAXON) nel Friuli Venezia-Giulia, sua possibilità di allevamento e ripopolamento. Camera di Commercio Industria, Artigianato e Agricoltura di Udine, Udine, vii + 45 p.

DE LUISE G., 1991. Diffusione, allevamento e ripopolamento in Friuli del gambero d'acqua dolce. Chiandetti Editore, Reana del Rojale (Udine), 176 p.

DEHUS P. ,1997. Flußkrebse in Baden-Württemberg. Broschüre, $2^{\text {te }}$ Auflage, Fischereifors chungsstelle des Landes Baden-Württemberg, Langenargen, $21 \mathrm{p}$.

DURIS Z., KOZÁK P., POLICAR, T. and THEIMER J., 2001. Rak kamenác Austropotamobius torrentium (SCHRANK) v Ceské republice. Casopis Slezkého Zemského Muzea, Série A Vedy Prírodní (Opava), 50 (supl.), 85-93.

ENTZ G., 1909. A magyarországi folyami rákoról. Állattani Közlemények (Budapest), 8, $37-$ $52+95+97-100+147+149-163+198-199+$ pl. 4-7. 
ENTZ G., 1914. Über die Flußkrebse Ungarns. Math. Naturwiss. Ber. Ungarn (Leipzig), Jahrgang 1912, 30, 67-127 + 4 pl.

FRANCKHAUSER R. and MACHINO Y., 2001. L'écrevisse de torrent (Austropotamobius torrentium) en France. L'Astaciculteur de France, septembre 2001, 68, 2-5.

FRANCKHAUSER R. and MACHINO Y., 2002. Notes astacologiques de Luxembourg, de Lorraine et de leurs environs. L'Astaciculteur de France, juin 2002, 71, 13-16.

FÜREDERL. and MACHINOY., 1995. Record of the white-clawed crayfish Austropotamobius pallipes (LEREBOULLET, 1858) from Plansee (Tyrol, Austria). Ber. Naturwiss.-Med. Ver. Innsbruck, 82, 241-246.

FÜREDER L. and MACHINO Y. ,1996. Das letzte natürliche Vorkommen des Steinkrebses Austropotamobius torrentium (SCHRANK, 1803), in Tirol. Ber. Naturwiss.-Med. Ver. Innsbruck, 83, 211-219.

HALGOS J. 1972. Príspevok k poznanju ektoparazitickych cervov radu Branchiobdellida na Slovensku (Annelida, Clitellita). Zbornik Slovenského Národného Múzea, Prírodné Vedy, 18 (1), 63-69.

HART C.W. Jr. and CLARK J., 1987. An interdisciplinary bibliography of freshwater crayfishes (Astacoidea and Parastacoidea) from Aristotle through 1985. Smithsonian Contributions to Zoology, 455, $437 \mathrm{p}$.

HOLDICH D.M., 2002. Distribution of crayfish in Europe and some adjoining countries. Bull. Fr. Pêche Piscic., 367, 611-650.

HORNIER E., COLLAS M., CLAUSS T., STORK F., ANDRÉ S. and HIESIGER P., 2002. L'écrevisse de torrrent (Austropotamobius torrentium) est toujours présente en Alsace. L'Astaciculteur de France, décembre 2002, 73, 6-10.

JANSKY V., 1987. Nález raka Austropotamobius torrentium v Dunaji pri Bratislave. Biológia, Séria B Zoologia (Bratislava), 42 (2), 197-205.

KAPPUS B., PEISSNER T. and RAWER-JOST C., 1999. Distribution and habitat conditions of crayfish populations in the urban freshwater systems of Stuttgart (BadenWürttemberg, Germany). Freshwater Crayfish, 12, 778-785.

KARAMAN M.S., 1962. Ein Beitrag zur Systematik der Astacidae (Decapoda). Crustaceana, 3, 173-191.

KINZELBACH R., 1986. The southern limit of the crayfishes species Astacus torrentium and $A$. astacus in Greece. Zoology in the Middle East (Heidelberg), 1, 145-146.

KLOS C. and KROTTEN J., 2001. Fische \& Flußkrebse des Saarlandes. Atlantenreihe, vol. 1, 111 p. Fischereiverband Saar, Dillingen (Saarland).

KOZÁK P., DURIS Z. and POLICAR T., 2002. The stone crayfish Austropotamobius torrentium (SCHRANK) in the Czech Republic. Bull. Fr. Pêche Piscic., 367, 707713.

LAURENT P.J., 1988. Austropotamobius pallipes and A. torrentium with observations on their interactions with other species in Europe. In HOLDICH D.M. and LOWERY R.S. (eds.), Freshwater crayfish: biology, management and exploitation. Croom Helm, London, p. 341-364 + 426-479.

LEREBOULLET A., 1858. Description de deux espèces d'écrevisses de nos rivières. Mém. Soc. Sci. Nat. Strasbourg, 5 (1), 11 p. +3 pl.

LOHNISKY K., 1984a. Poznámky k soucasnému vyskytu raka kamenáce Austropotamobius torrentium (SCHRANK, 1803) v Cechách. Casopis Národního Muzea, Rada Prírodovedná (Praha), 153 (4), 195-201. 
LOHNISKY K., 1984b. Rozsírní raku ve vychodních Cechách a jeho zmeny v posledních desetiletích. Zpravodaj KMVC Prírodni Vedy, Krajské Muzeum Vychodních Cech se sídem v Hradci Králové, 11 (2), 5-27.

LOHNISKY K., 1990. Les écrevisses de Bohème orientale (Tchécoslovaquie): changements récents, état actuel et perspectives. L'Astaciculteur de France, mars 1990, 22, 2-7.

MACHINO Y., 1996. L'écrevisse de torrent Austropotamobius torrentium (SCHRANK, 1803) est bord de l'extinction en Italie. L'Astaciculteur de France, décembre 1996, 49, 9-12.

MACHINO Y., 2000. Les écrevisses au Luxembourg. L'Astaciculteur de France, mars 2000, 62, 2-6.

MACHINO Y. ,2001. Novelle observation astacologique au Luxembourg. L'Astaciculteur de France, mars 2001, 66, 2-3.

MACHINO Y. and DURIS Z., 2004. New data and verification on the geographical distribution of the crayfish genus Austropotamobius from Bosna-i-Hercegovina, Montenegro and Bulgaria. Crayfish News-IAA Newsletter, February 2004, 26 (1), 8-10.

MACHINO Y. and FÜREDER L., 1998. Der Steinkrebs Austropotamobius torrentium (SCHRANK, 1803) im Haldensee (Tirol, Österreich) und weitere Nachweise von Flußkrebsen in hochgelegenen Gewässern. Ber. Naturwiss.-med. Ver. Innsbruck, 85, 223-229.

MACHINO Y. and HOLDICH D.M. In press. Distribution of crayfish in Europe and adjacent countries: updates and comments. Freshwater Crayfish, 15.

MAGUIRE I., ERBEN R., KLOBUČAR G.I.V. and LAJTNER J., 2002. Year cycle of Austropotamobius torrentium (SCHRANK) in streams on the Medvednica Mountains (Croatia). Bull. Fr. Pêche Piscic., 367, 943-957.

MARCU O., 1930. Die Süßwasserdekapoden und ihre Verbreitung in der Bukowina. Verh. Mitt. Siebenb. Ver. Naturwiss. Hermannstad, Jahrgang 1929/1930, 79/80, 86-88. (Hermannstadt $=$ Sibiu)

MATIS D., 1971. Správa o náleze raka Austropotamobius torrentium (SCHRANK, 1803) na Slovensku. Zborník Slovenského Národného Múzea, Prírodné Vedy, 17 (2), 135136.

MEINEL W. and MOCK T., 2001. Vorkommen der zehnfüßigen Krebse in Hessen: Bestandssituation, Verbreitung, Gefährdung und Schutz. Hessisches Ministerium für Umwelt, Landwirschaft und Forsten, Wiesbaden, $72 \mathrm{p}$.

ORTVAY T., 1902. Pozsonyvármegye és a területén fekvö Pozsony, Nagyszombat, Bazim, Modor s Szentgyörgy városok állatvilága. Stampel Károly, Pozsony (=Bratislava), 448 p. (not seen)

PETUTSCHNIG J., 1993. Das Steinkrebsvorkommen im Einzugsgebiet des Trattenbaches. Jahrbuch des Oberösterreichischen Musealvereines, Abhandlungen (Linz), 138, 279-307.

POLICAR T. and KOZÁK P., 2000. Vyskyt raku CR. Bulletin - Výzkumny Ústav Rybárský a Hydrobiologicky ve Vodnanech, 36 (1/2), 18-22.

PUKY M., 2000. Distribution of Decapoda species along the Hungarian Danube section and some tributaries with special emphasis on their conservation status. In HORVATIC J. (ed.), Limnological Reports: Proceedings of the 33rd conference of the Internationale Arbeitsgemeinschaft Donauforschung. Faculty of Education, Josip Juraj Strossmayer University, Osijek (Croatia), p. 285-290. 
RENZ M. and BREITHAUPT T., 2000. Habitat use of the crayfish Austropotamobius torrentium in small brooks and in Lake Constance, southern Germany. Bull. Fr. Pêche Piscic., 356, 139-154.

REPA J., 1999. Schwäbischer Fischatlas: Untersuchungsergebnisse der Jahre 1990-1995. Fachberatung für Fischerei, Bezirk Schwaben, Augsburg, 136 p.

SCHADT J., 1993. Fische, Neunaugen, Krebse und Muscheln in Oberfranken - Atlas der Arten. Fachberatung für Fischerei, Bezirk Oberfranken, Bayreuth, 136 p.

SCHANZH. and FROEHLICH C. 1991. Zur Verbreitung des Steinkrebses (Austropotamobius torrentium Schrank) im Mittelrheingebiet. Fauna Flora Rheinland-Pfalz (Landau), 6 (3), 647-653.

SCHULZ N. and KIRCHLEHNER W. 1984. Der Steinkrebsbestand Astacus torrentium (Schrank) im Spintikbach (Kärnten, Österreich). Österreichs Fischerei, 37, 47-57.

SCRIBAN I.A., 1908. Note sur les écrevisses de Roumanie. Annales Scientifiques de I'Université de Jassy, 5, 80-83. (Jassy = lasi).

STAROBOGATOV Ya.I., 1995. Taxonomy and geographical distribution of crayfishes of Asia and East Europe (Crustacea Decapoda Astacoidei). Arthropoda Selecta (Moscow), 4 (3/4), 3-25.

STEINBERG L., 1992. Fische unserer Bäche und Flüsse, Verbreitung, Gefährdung und Schutz in Nordrhein-Westfalen. Ministerium für Umwelt, Raumordnung und Landwitschaft des Landes Nordrhein-Westfalen, Düsseldorf, $121 \mathrm{p}$.

STREISSL F. and HÖDL W. 2002. Populationsdichte und jahreszeitliche Aktivität des Steinkrebses (Austropotamobius torrentium) in ökomorphologisch verschiedenen Abschnitten des Biberbachs (Niederösterreich). Österreichs Fischerei, 55, 49-57.

SUBCHEV M. and STANIMIROVA L., 1998. Razprostranenie na pravite sladkovodni raci (Crustacea: Decapoda) i tehnite epibionti ot rod Branchiobdella (Annelida: Branchiobdellae), Hystricosoma chappuisi Michaelsen, 1926 (Annelida: Ologochaeta) i Nitocrella divaricata (Crustacea: Copepoda) v Bylgarija. Historia Naturalis Bulgarica, 9, 5-18.

THIENEMANN A., 1950. Verbreitungsgeschichte der Süßwassertierwelt Europas. Binnengewässer (Stuttgart), 18, xvi + 809 p. + 11 pl.

THURÁNSZKY M. and FORRÓ L., 1987. Data on the distribution of freshwater crayfish (Decapoda: Astacidae) in Hungary in the late 1950s. Miscellanea Zoologica Hungarica, 4, 65-69.

TRONTELJ P., MACHINO Y. and SKET B., 2005. Phylogenetic and phylogeographic relationships in the crayfish genus Austropotamobius inferred from mitochondrial COI gene sequences. Mol. Phylogenet. Evol. , 34, 212-226.

TROSCHEL H.J. and BARTL G. 1998. Fische in Luxemburg. Service de la Chasse et de la Pêche, Administration des Eaux et Forêts de Luxembourg, Luxembourg, 168 p.

TROSCHEL H.J. and DEHUS P. 1993. Distribution of crayfish species in the Federal Republic of Germany, with special reference to Austropotamobius pallipes. Freshwater Crayfish, 9, 390-398.

WOLSKY A. 1934. Sauerstoffverbrauch und Körpergewicht beim Steinkrebs (Potamobius torrentium [SCHRANK] ORTMANN) nebst kritischen Bemerkungen über die Methoden der Bestimmung des Sauerstoffverbrauches. Magyar Biológiai Kutató Intézet Munkái (Tihany), 7, 116-125. 
